\title{
The Arabian Sea - Marine Pollution Viz A Viz Existence and Implementation of International Preventative Laws
}

Mobin Siddiqi, Rafia Azmat

\begin{abstract}
Tremendously increasing marine pollution is a global threat to the survival of humanity. The correlation between marine pollution and devastating impact on ecological systems and other spheres of environment have already been proven. Marine pollution is not a localized phenomenon and has its effects on a global scale; this leads to formulation of certain international regulations mutually agreed by signatory nations. However, in certain parts of the world, including the Indian Ocean, compliance with regulations is notobservable. Unsolved partof the puzzle is; why marine pollution continues to exist notwithstanding the evidence that it is so very dangerous. To answer this question, economic, legal, political, scientific, social and technological factors need to be brought under consideration. This study serves a twofold purpose; firstly, it enquires into the deliberation on international law regarding marine pollution in this region; secondly, it identifies the quantity and quality of the main sources of marine pollution in the Indian Ocean.

An attempt has been made to identify main sources of marine pollution in Indian Ocean followed by a chemical classification of pollutants and extrapolating their temporal impacts on bio-diversity of the region. Understanding ofpollution sources that affect Indian Ocean provide better insight for planning and implementation of the necessary regime to prevent, reduce and control marine pollution in the Arabian Sea. Qualitative and quantitative chemical analysis performed in the region, using advanced analytical techniques to prevent, control and eliminate marine pollution viz-à-viz various conventions put in place in the region depict that strict compliance of the protocols is need of time to save the oceans from getting polluted beyond the limit of retrieval to original state.
\end{abstract}

Keywords: Marine Pollution, International Laws, Maritime Zones, Ocean governance. 


\section{Introduction}

Oceans and seas are the soul of our planet. Oceans cover about threequarters of planet earth and carry $97 \%$ of earth's water. More than 50\% of atmospheric oxygen is produced through the oceans, and they absorb significant number of oxides of carbon from the air. Coastal zones are habitat of about half of the world's population, and ocean-based businesses contribute more than $\$ 500$ billion to the world's economy. In past years, it was believed that, it is not possible to take too much out of, or put too much waste into, the oceans. This misconception has brought our environment at the point where it is necessary to take immediate remedial measures and stop further polluting the oceans for survival of our offspring on this planet. Human intervention in the natural marine ecosystem has created problems such as overharvest of resources, reduction in biodiversity, and degradation of marine habitats and species, among others.

This research study was conducted on Indian Ocean and its marginal seas with special focus to the Arabian Sea. The Arabian Sea is a northwestern extension of the Indian Ocean, positioned between Yemen, Pakistan, Oman, India and, and Cape Guardafui in far north-eastern Somalia. The Indian Ocean is the world's third largest ocean and has an area of $70,560,000 \mathrm{~km}^{1}$. It is bounded by Asia on the north, on the west by Africa, on the east of Australia, and on the south by the Southern Ocean as delineated by the International Hydrographic Organization in the year 2000. Average depth of Indian Ocean is $3873 \mathrm{~m}$ and its deepest trench is Diamantine Trench, at 8,047 $\mathrm{m} \mathrm{depth}^{2}$.

1 Dietrich, G. (1973). "The unique situation in the environment of the Indian Ocean" in The Biology of the Indian Ocean, eds., Bernt Zeitzchel and Sebastian A. Gerlach, (Springer, Verlag, Berlin, 1973), 1-6.

2 National Institute of Oceanography, "A study of Estuarine Environments of Major Indian Rivers" -Ganga and Mahimadi Estuaries. Technical Report NIO/TR/4/86, (2016) 


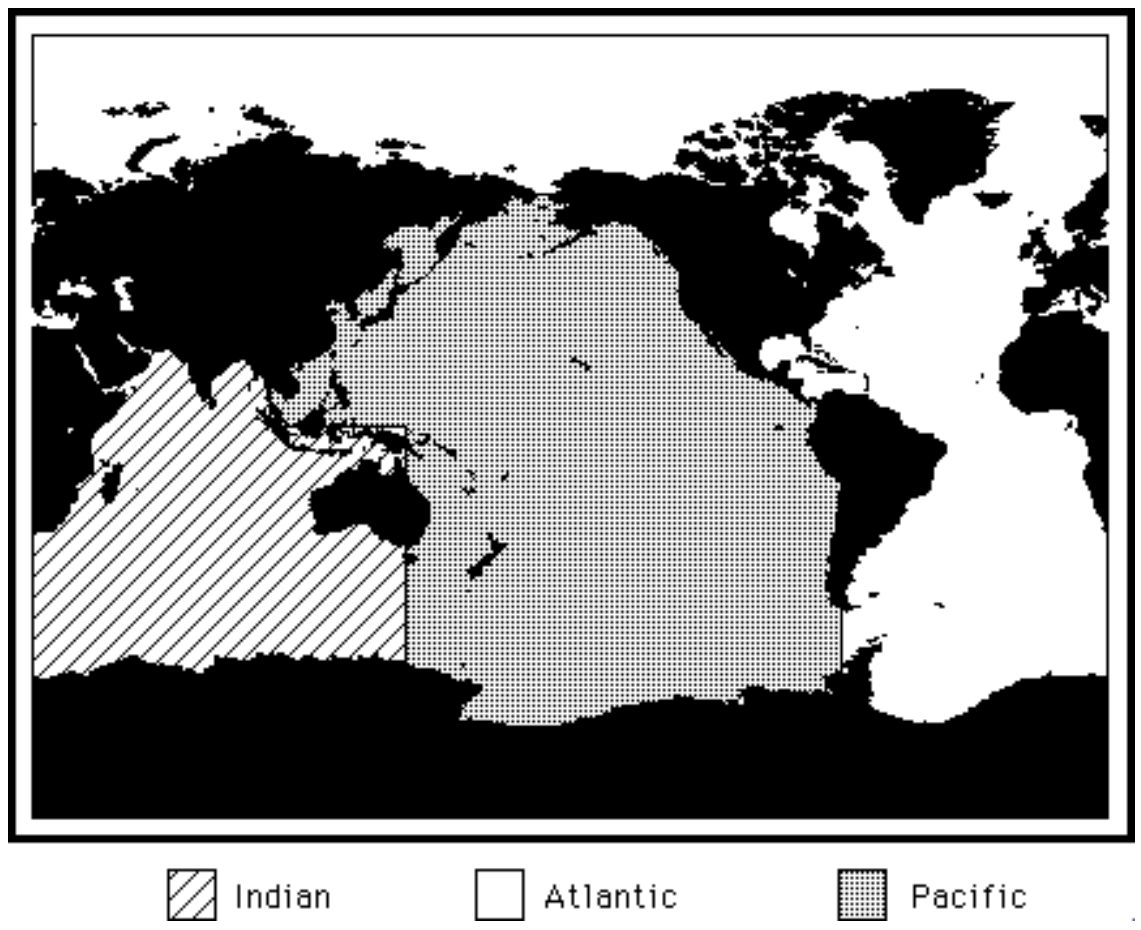

Figure 1. Delineation of Indian Ocean by International Hydrographic Organization

The geographical coordinates of Indian Oceanboundary are given in table 1 Contrary to common perception about inter connected waters in oceans, each water mass has a system of oceanic currents which drives

\begin{tabular}{|c|c|c|}
\hline Longitude band & Southern Latitude & Northern Latitude \\
\hline $020 \mathrm{E}-100 \mathrm{E}$ & $80 \mathrm{deg} . \mathrm{S}$ & $31 \mathrm{deg} . \mathrm{N}$ \\
\hline $100 \mathrm{E}-145 \mathrm{E}$ & $80 \mathrm{deg} . \mathrm{S}$ & $0 \mathrm{deg}$. \\
\hline
\end{tabular}

Table 1: Indian Ocean Boundary Coordinates

its mixing potentials. The balance between inputs and outputs of water in an ocean is known as the water balance. The water balance can be shown using the formula:

$\mathrm{B}=\mathrm{Q}+\mathrm{E}-\mathrm{P} \pm \mathrm{dS}$ eq 1 
Where

$\mathrm{B}=$ Balance of Water

$\mathrm{P}=$ Precipitation

$\mathrm{Q}=$ Stream Flow $/$ Runoff water from rivers

$\mathrm{E}=$ Evaporation

$\mathrm{dS}=$ Changes in Storage capacity

If the value of $\mathrm{P}$ in equation 1 is a positive input of water is more than water removed and vice versa. Mathematical conditions mentioned in table 2 will govern the water balance cycle:

\begin{tabular}{|c|c|c|}
\hline Condition & Change in ocean water & Water balance \\
\hline $\mathrm{B}>0$ & $\begin{array}{c}\text { Means the water in the ocean is } \\
\text { increasing }\end{array}$ & $\begin{array}{c}\text { Positive water } \\
\text { balance cycle }\end{array}$ \\
\hline $\mathrm{B}=0$ & $\begin{array}{c}\text { Means that water amount is } \\
\text { constant }\end{array}$ & $\begin{array}{c}\text { Balanced water } \\
\text { cycle }\end{array}$ \\
\hline $\mathrm{B}<0$ & $\begin{array}{c}\text { Means that the water in the } \\
\text { ocean is decreasing }\end{array}$ & $\begin{array}{c}\text { Negative water } \\
\text { balance cycle }\end{array}$ \\
\hline
\end{tabular}

Table 2: Water balance conditions based on water cycle equation (eq 1)

The water balance affects how much water is stored in a system. The Indian Ocean in general is a sea of negative water balance. It gets 6,000 $\mathrm{km}^{3}$ of waterrunoff and $88,000 \mathrm{~km}^{3}$ of precipitation. While its evaporation is $1,03,000 \mathrm{~km}^{3}$

Substituting the values in equation 1

$\begin{array}{llllll}\mathrm{B} & =\mathrm{Q} & +\mathrm{P} & -\mathrm{E} & \pm \mathrm{dS} \\ -9000 & =6000+88000 & -103000 \pm 0\end{array}$

However, there are a few regions of the Indian Ocean, for example, the Bay of Bengal where the water balance is positive. The Arabian Sea is 
an area of negative water balance where on the entire the dissipation is more than its precipitation ${ }^{3,4}$. Most elevated dissipation happens off the Arabian drift. It diminishes relentlessly towards southeast. Along the southwest bank of India, there is a slight abundance of precipitation over dissipation $(>20 \mathrm{~cm})^{5}$.

The Bay of Bengal has a region of $4.087 \times 10^{6} \mathrm{~km}^{2}$ between latitudes $0^{\circ}$ and $22^{\circ} \mathrm{N}$ and longitudes $80^{\circ}$ and $100^{\circ} \mathrm{E}$. It gets every year a precipitation of $11000 \mathrm{~km}^{3}$ furthermore, a spillover of around 2000 $\mathrm{km}^{36}$. This gives a yearly weakening of around $5 \%$ for the upper 25 meters, which can be expected as the greatest profundity of riverine impact in the Bay of Bengal7.

Almost all the countries bordering the Indian Ocean are developing countries. Their major sources of revenue is agriculture, industry, and in some countries also mining. The effects of pollution in the marine environment began to be felt very recently, although these activities are continuing for a long times.

The pollution problems are felt largely near the coastal waters mainly because of the flow of waters nature of the bottom topography and constant release of domestic and industrial discharges resulting from the

3 Qasim, S.Z. and Sen Gupta, R. "Present status of marine pollution studies in India,” In Management of Environment, Eds,.B. Patel \& W. Eastern, (New Delhi, 1980), 310-329.

4 Qasim, S.Z. and Sen Gupta, R. (1983), a. "Marine Pollution Studies in India," In Water Pollution and Management Reviews, eds., C.K. Varshney, (New Delhi, South Asian Publishers, 1983), 139-159.

5 Qasim, S.Z., and Sen Gupta, R, "Environmental Characteristics of the Ocean". In Environmental Sciences and Engineering, ed., James R, Prafflin \& Edward N. Ziegler, (New York, Gordon and Breach Science publishers, b, 1983), 294-309

6 Qasim, S.Z., and Sen Gupta, R., "Some problems of coastal Pollution in India," Marine Pollution Bulletin, 19, (1988), 100-106.

7 Sen Gupta, R., Naik, S., and Singbal, S.Y.S., "A study of fluoride, calcium and magnesium in the Northern Indian Ocean," Marine Chemistry, 6, (1978), 125141.

8 Sen Gupta, R. and Kureishy, T.W., "Present State of Oil Pollution in the Northern Indian Ocean,” Marine Pollution Bulletin, 12, (1981), 295-301. 
increasing urbanization and industrialization throughout the region. Many rivers flowing through the landmass receives the domestic and industrial discharges and contribute substantially to the degradation of the adjoining seas ${ }^{9}$.

\section{Nature of Environmental Problems}

The term pollution refers to a deviation from the purity. When the term polluted water is used, it is in reference to water in its pristine state. Any substance that makes water unfit for human utilization or is considered harmful to natural habitat, is categorized as a pollutant. In most of the situations environmental pollution is not a direct human action aimed towards harming the environment, rather it is a consequence of another action deemed favourable for human development or comfort. Pollutants are not necessarily man-made substances; they can be natural substances disproportionately displaced from the sites or states of their natural occurrences.

\section{Oil Pollution}

Oceans are dangerously affected by oil pollution, where term oil refers to crude petroleum or refined petroleum products. Oil pollution is an inevitable consequence of the dependence of a rapidly growing population on oil-based technology.

Accidental oil spills during transportation of huge quantities is a rare occurring, but its impact can be equated to that of an atomic explosion. Since 1901 up-to-date 71 oil spills of magnitude over 10,000 tones have taken place. Moreover, oil originating from the ballast, bilge and cooling water of the tankers are the main sources of oil contamination in the Indian Ocean. Due to rapid industrialization domestic and industrial effluent is also contributing significant towards the marine oil pollution. Oil pollution has both short-termand long term effects. Short term effectsinclude:

- Acute toxicity

- Asphyxiation and covering of avifauna and benthic fauna

- Dissolved oxygen reduction

9 Qasim, S.Z., Sen Gupta R., and Kureishy, T. W. (1988). "Pollution of the seas around India," Proceedings of Indian of Sciences, Animal Science, 97, (1988), 117-131. 
- Reduction of light transmission in the sea

- Deposition of tarry lumps (the end-product of oil reaching the marine environment) on the beaches.

Long term effects of oil pollution in oceans persist in the marine environment for many years after an oil spill, especially in salt marshes and mangrove swamps, the effects may be measurable for decades after the event ${ }^{10}$. Oil spill reduces marine population as a result of short term effects, which in return affect the population growth cycles of marine life, thus disturbs the whole ecological balance of not only marine life but also birds and land animals.

\section{Heavy Metal Pollution}

Marine Pollination due to oil is a prominent cause of pollution and remains in limelight in print and broadcast media as well as research organizations. However, there are other forms of pollution, which have even more adverse effect on marine environment. One of these sources is the toxic heavy metals. Sources of Heavy metal pollution are both natural and through human activities. Natural processes include underwater volcanic activity, weathering etc whereas submarine metal ores and petroleum extraction cause heavy metal pollution.

The list is not limited to these two activities, it also includes atmospheric transport, river runoff and domestic and industrial discharges of some of the metals from under-sea deposits are removed, smelted and refined, for use in industries. Each of the above mentioned processes introduces considerable amounts of metals in the marine environment where its resistant nature and prolonged stability makes it bio-available for a very long time. Some of the metals are determined to be present in oceans and causing adverse effects on environment include mercury ( $\mathrm{Hg}$ ), cadmium (Cd) and lead (Pb). Each one of these metals have a catastrophic event associated to it. For example, Minamata and Itai-Itaiare human diseases caused by consumption of fish contaminated by Hgand Cd respectively.

10 Paul F. Kingston, "Long-term environmental impact of oil spills," Spill Science \& Technology Bulletin, 7, no. 1, (2002): 53-61. 
Like most of the organic pollutants, metals cannot be degraded biologically or chemical in nature. They can undergo chemical reactions to change their oxidation state ,but not be removed. It is also alarming that a few metals after undergoing chemical reactions yield products with higher toxicity levels. Heavy metals can also alter several enzymesrelated biological functions of living cells. One of the most serious threats of metal pollution is biological magnification in the food chain, resulting in some plants and animals becoming a health hazard when used as food.

\section{Plastic Debris}

Dumping of plastic debris is illegal throughout the world's oceans. Plastics are organic polymers and are major macroscopic pollutants. Plastics are lightweight, strong and durable and also float. The polymers when exposed to UV radiation in sunlight break into smaller and smaller pieces, but they are still present as plastic, and they are nonbiodegradable in any practical manner. Plastics are main marine litter, with abundance ranging from $60 \%$ to $80 \%$ of the total marine debris. Over the past 20 years polychlorinated biphenyls (PCBs) have increasingly polluted marine food webs, and are prevalent in sea birds.

\section{Agricultural Wastes}

For human survival, it is necessary to wage a battle against natural pests like insects, weeds and molds . According to estimates, 141 Million tons of fertilizer were used worldwide in 2002 and 1.3 Million tons of pesticide were used in 1999 for agriculture pest control and disease vector control. Pesticides are classified according to their target or their chemical composition and structure. Out of the quantity of pesticides used nearly $25 \%$ can be expected to reach the marine environment through the atmosphere, river runoff and direct discharges. Some of these pesticides are persistent with 'half-life' of nearly a decade and they are distributed through various segments of the marine environment. Agricultural compounds induce following prominent effects on marine and related life forms:

- Affects the mortality rate of the young fishes

- Accumulate in body tissues to the extent that these animals are rendered unfit for human consumption

- Cause Reproduction problems in marine animals 
- Induce behavioral changes in marine animals.

\section{Domestic Wastes}

Domestic wastes are high in organic matter, including Nitrogen and Phosphorus. These substances are essentially required by the marine ecological system, however large quantities have harmful effects and cause imbalance in a coastal environment especially breeding of pathogenic bacteria. Addition of excess $\mathrm{N}$ and $\mathrm{P}$ to marine environment causes eutrophication (over-fertilization). Eutrophication may result in prolific growth of algae of a resistant type limiting the species diversity, which disrupts the ecological balance tremendously. Domestic waste also contains significant amounts of inorganic constituents which though are essential for animal growth and fertility of the sea in smaller amounts, cause great damage to the environment when added uncontrolled. Coastal tourism is promoted by countries to earn foreign exchange for which construction of large hotels and other economic activity area are developed. Domestic wastes from these places pose serious environmental issues for the adjacent marine areas ${ }^{11}$.

\section{Marine Pollution Prevention Treaties and Convention}

At the international level, there have been a number of initiatives taken by the international community to address the marine pollution problem. The international instruments relating to marine pollution and signed by Indian Ocean countries are discussed briefly in chronological order below:

The International Convention for the Prevention of Pollution of the Sea by Oil (1954): The convention was first attempt to prevent pollution of the sea by oil tankers. It prohibited the discharge of oil or oil mixture by tankers within prohibited zones from the coastline.

The Geneva Convention on the High Seas (1958): The convention contains two Articles, i.e., Article 24 and 25 on marine pollution and through this Convention states were obliged to cooperate with the competent international organizations in taking measures to prevent

11 S.W.A Naqvi, "Some aspect of the oxygen deficient conditions and denitrification in the Arabian Sea," Journal of Marine Research, 45, (1987): 1049-1072. 
the pollution. From among the South Asian countries, Nepal, Pakistan and Sri Lanka are parties to this Convention.

International Convention Relating to Intervention on the High Seas in Cases of Oil Pollution Casualties (1969): It is a multilateral treaty which empowers the coastal states to take measures beyond the limits of their territorial sea in case of maritime casualty involving oil pollution from ships which may cause major harmful consequences.

The International Convention on Civil Liability for Oil Pollu tion Damage (1969): CLC creates a scheme of liability for oil pollution damage caused by oil tankers and further provides that the ship owner is strictly liable for oil pollution damage, without any need to prove negligence or fault except in certain circumstances, e.g. war and insurrection.

The Convention on the Prevention of Marine Pollution by the Dumping of Wastes and other Matter (1972): It regulates the deliberate disposal of certain substances at sea, including oily wastes, dredging and land-generated wastes, excluding the oil pollution caused by normal operational discharges of ships and pollution caused by maritime casualties. Pakistan and Afghanistan are parties to this Convention.

The Convention for the Prevention of Pollution from Ships 1973 (1973 MARPOL Convention): The convention aims to prevent the marine environment pollution caused by the operational discharge of oil and other harmful substances and to minimize the accidental discharge of such substances. MARPOL is divided into Annexes according to various categories of pollutants, each of which deals with the regulation of a particular group of ship emissions. All six Annexes have been ratified by the requisite number of nations; the most recent is Annex VI, which took effect in May 2005. The country where a ship is registered (Flag State) is responsible for certifying the ship's compliance with MARPOL's pollution prevention standards.

Annex I (1983): MARPOL Annex I deal with discharge of oil into the ocean environment. It specifies tanker design features to minimize oil discharge during ship operations and accidents. It regulates treatment of engine room bilge water (OWS) and tank cleaning waste (ODME). The Oil Record Book is another integral part of MARPOL 
Annex I. The Oil Record Book helps crew members log and keep track of oily waste water discharges among other things.

Annex II (1987): MARPOL Annex II details the discharge criteria for the elimination of pollution by noxious liquid substances carried in large quantities. The discharge of pollutants is allowed only to reception facilities with certain concentrations and conditions. No matter what, no discharge of residues containing pollutants is permitted within 12 miles of the nearest land.

Annex III (1992): MARPOL Annex III contains general requirements for the standards on packing, marking, labelling, documentation, stowage, quantity limitations, exceptions and notifications for preventing pollution by noxious substances. The Annex is in line with the procedures detailed in the International Maritime Dangerous Goods (IMDG) Code, which has been expanded to include marine pollutants. The amendments entered into force on 1 January 1991.

Annex IV (2003): MARPOL Annex IV came into force on 22 September 2003. It introduces laws and regulation related to control of pollution at sea due to sewage from ships.

Annex V (1988): MARPOL Annex V specifies the distances from land in which materials may be disposed off and subdivides different types of garbage and marine debris. The requirements are much stricter in a number of "special areas" but perhaps the most prominent part of the Annex is the complete ban on dumping plastic into the ocean.

Annex VI (2005): MARPOL Annex VI introduces requirements to regulate the air pollution being emitted by ships, including the emission of ozone-depleting substances, Nitrogen Oxides (NOx), Sulphur Oxides (SOx), Volatile Organic Compounds (VOCs) and shipboard incineration.

\footnotetext{
International Convention Relating to Intervention on the High Seas in Cases of Oil Pollution Casualties (1969): The 1969 Intervention Convention applied to casualties involving pollution by oil. In view of the increasing quantity of other substances, mainly chemical, carried by ships, some of which would, if released, cause a serious hazard to the marine environment, the 1969 Brussels Conference recognized the need to extend the Convention to cover substances other than oil.
} 
Convention on the Prevention of Marine Pollution by Dumping of Wastes and Other Matter (LC), 1972 (and the 1996 London Protocol): The London Protocol stresses the "precautionary approach", which requires that "appropriate preventative measures are taken when there is reason to believe that wastes or other matter introduced into the marine environment are likely to cause harm ,even when there is no conclusive evidence to prove a causal relation between inputs and their effects".

It also states that "the polluter should, in principle, bear the cost of pollution" and emphasizes that Contracting Parties should ensure that the Protocol should not simply result in pollution being transferred from one part of the environment to another.

International Convention on Oil Pollution Preparedness, Response and Co-operation (OPRC) (1990): Signatory nations are required to establish measures for dealing with pollution incidents, either nationally or in co-operation with other countries. Ships are required to carry a shipboard oil pollution emergency plan. Operators of offshore units under the jurisdiction of Parties are also required to have oil pollution emergency plans or similar arrangements which must be co-ordinated with national systems for responding promptly and effectively to oil pollution incidents. A Protocol to the OPRC relating to hazardous and noxious substances (OPRC-HNS Protocol) was adopted in 2000. Like the OPRC Convention, the OPRC-HNS Protocol aims to establish national systems for preparedness and response and to provide a global framework for international cooperation in combating major incidents or threats of marine pollution.

International Convention on the Control of Harmful Anti-foul ing Systems on Ships (2001): The Convention prohibits the use of harmful organotins (tin based hydrocarbons) in anti-fouling paints which slowly "leach" into the sea water and persist, killing barnacles and other marine life that have attached to the ship moreover harming the environment and possibly entering the food chain. Antifouling paints are used to coat the bottoms of ships to prevent sea life such as algae and molluscs attaching themselves to the hull - thereby slowing down the ship and increasing fuel consumption.

Under the terms of the AFS Convention, Parties to the Convention are required to prohibit and/or restrict the use of harmful anti-fouling systems on ships flying their flag, as well as ships not entitled to fly 
their flag ,but which operate under their authority and all ships that enter a port, shipyard or offshore terminal of a Party.

International Convention for the Control and Management of Ships' Ballast Water and Sediments (BWM) (2004): Invasive aquatic species present a major threat to the marine ecosystems, and shipping has been identified as a major pathway for introducing species to new environments. The problem increased as trade and traffic volume expanded over the last few decades and in particular with the introduction of steel hulls, allowing vessels to use water instead of solid materials as ballast. Ballast Water Management Convention, adopted in 2004, aims to prevent the spread of harmful aquatic organisms from one region to another, by establishing standards and procedures for the management and control of ships' ballast water and sediments. Under the Convention, all ships in international traffic are required to manage their ballast water and sediments to a certain standard, according to a ship-specific ballast water management plan.

A summary of important conventions and protocols implemented by mutual consent of Indian Ocean coastal countries is placed at table 3 .

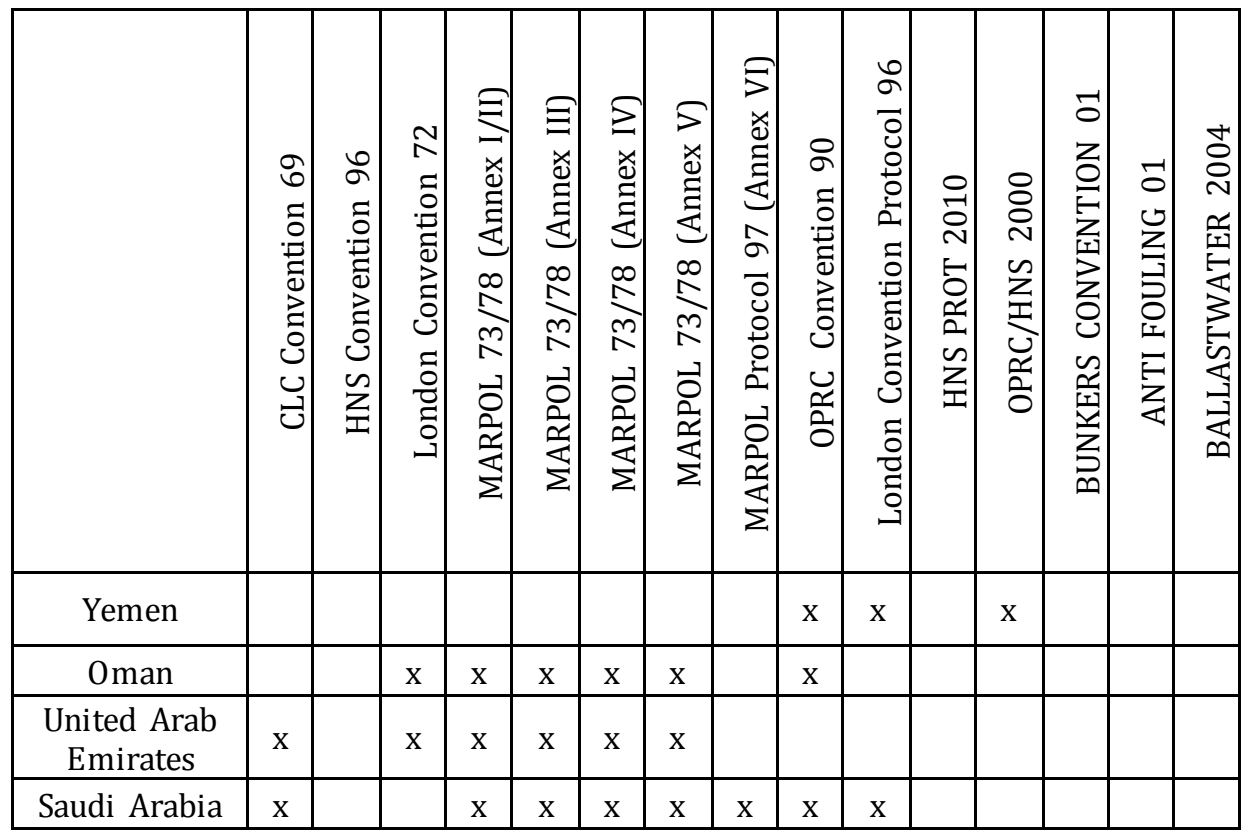




\begin{tabular}{|c|l|l|l|l|l|l|l|l|l|l|l|l|l|l|l|}
\hline Iraq & & & & & & & & & & & & & & & \\
\hline Iran & & & $\mathrm{x}$ & $\mathrm{x}$ & $\mathrm{x}$ & $\mathrm{x}$ & $\mathrm{x}$ & $\mathrm{x}$ & $\mathrm{x}$ & $\mathrm{x}$ & & $\mathrm{x}$ & $\mathrm{x}$ & $\mathrm{x}$ & $\mathrm{x}$ \\
\hline Pakistan & & & $\mathrm{x}$ & $\mathrm{x}$ & $\mathrm{x}$ & $\mathrm{x}$ & $\mathrm{x}$ & & $\mathrm{x}$ & & & & & & \\
\hline India & & & & $\mathrm{x}$ & $\mathrm{x}$ & $\mathrm{x}$ & $\mathrm{x}$ & $\mathrm{x}$ & $\mathrm{x}$ & & & & & $\mathrm{x}$ & \\
\hline Sri Lanka & & & & $\mathrm{x}$ & $\mathrm{x}$ & $\mathrm{x}$ & $\mathrm{x}$ & & & & & & & & \\
\hline Bangladesh & & & & $\mathrm{x}$ & $\mathrm{x}$ & $\mathrm{x}$ & $\mathrm{x}$ & $\mathrm{x}$ & $\mathrm{x}$ & & & & & & \\
\hline Myanmar & & & & $\mathrm{x}$ & $\mathrm{x}$ & $\mathrm{x}$ & $\mathrm{x}$ & & $\mathrm{x}$ & & & & & & \\
\hline Indonesia & $\mathrm{x}$ & & & $\mathrm{x}$ & $\mathrm{x}$ & $\mathrm{x}$ & $\mathrm{x}$ & $\mathrm{x}$ & & & & & $\mathrm{x}$ & $\mathrm{x}$ & $\mathrm{x}$ \\
\hline
\end{tabular}

Table 3. Country wise status of conventions

$\mathrm{X}=$ Signed the treaty

\section{Marine Pollution Studies}

The general levels of marine contamination in the Indian Ocean district may not be noteworthy. The beach front populace is moderately low and mechanical exercises are yet to take off at a quick pace. In any case, in the region of urban and modern combinations along the drift intense issues of contamination have been watched making harm nature and constituting perils to general wellbeing. Contamination control measures in the greater part of the nations are either lacking or missing12.

Heavy metal concentrations in different regions of the Indian Ocean have been determined by researchers as shown in Table 4 . The data depict that despite regulations, the concentration of heavy and toxic metals Indian Ocean water is higher as compared to unpolluted sea water composition. Similar data for oil, pesticides, fertilizers and plastic debris is available and are all exhibiting the increased pollutant concentrations in the region. 


\begin{tabular}{|c|c|c|c|c|c|c|}
\hline $\begin{array}{c}\text { As at } \\
10 / 01 / 2017\end{array}$ & $\mathrm{Mn}$ & $\mathrm{Zn}$ & $\mathrm{Cu}$ & $\mathrm{Pb}$ & $\mathrm{Co}$ & $\mathrm{Cr}$ \\
\hline Yemen $^{13}$ & 335.5 & 128.59 & 19.89 & 77.28 & 23.97 & 82.19 \\
\hline Oman $^{14}$ & 8.6 & 1690 & 170 & 4.7 & 1 & 0.5 \\
\hline $\begin{array}{c}\text { United Arab } \\
\text { Emirates }\end{array}$ & 96.6 & - & 1.92 & 2.1 & 1.16 & 31.7 \\
\hline $\begin{array}{c}\text { Saudi } \\
\text { Arabia } 16\end{array}$ & - & 1253 & - & 3.8 & 45 & 303 \\
\hline Iraq $^{17}$ & 50 & 14 & 2.6 & 4 & 2 & - \\
\hline Iran $^{18}$ & - & 42 & 18 & 11.5 & - & 32 \\
\hline Pakistan $^{19}$ & 300 & 15.6 & - & 9 & - & 319 \\
\hline India $^{20}$ & 4643.1 & 1483.43 & 312.87 & 169.98 & 111.42 & 290.18 \\
\hline
\end{tabular}

13 Nasr, S.M., Okbah, M.A., \&Kasem, S.M. (2006). Environmental assessment of heavy metal pollution in bottom sediments of Aden Port, Yemen. International Journal of Oceans and Oceanography, 1(1), 99-109.

14 K.A. Burns, J.P. Villeneuve, V.C. Anderlin, and S.W. Fowler, "Survey of tar, hydrocarbon and metal pollution in the coastal waters of Oman," Marine Pollution Bulletin, 13, no. 7, (1982): 240-247.

15 M. I. El Samra and K.Z. El Deeb, "Horizontal and vertical distribution of oil pollution in the Arabian Gulf and the Gulf of Oman," Marine Pollution Bulletin, 19, no. 1, (1988): 14-18.

16 Stephen de Mora, Scott W. Fowler, Eric Wyse, and Sabine Azemard, "Distribution of heavy metals in marine bivalves, fish and coastal sediments in the Gulf and Gulf of Oman," Marine Pollution Bulletin, 49, no.5, (2004): 410424.

17 Humood A. Naser, "Assessment and management of heavy metal pollution in the marine environment of the Arabian Gulf: a review. Marine Pollution Bulletin, 72, no.1, (2013): 6-13.

18 A.H Al-Hashimi, H.H Salman, Trace metals in the sediments of the northwestern coast of the Arabian Gulf," Marine Pollution Bulletin, 16, no.3, (1985): 118-120.

19 Azhar Mashiatullah, Muhammad Zaman Chauhdhry, Nasir Ahmad, , Tariq Javed, and Abdul Ghaffar, "Metal pollution and ecological risk assessment in marine sediments of Karachi Coast, Pakistan," Environmental Monitoring and Assessment, 185, no.2, (2013): 1555-1565.

20 Kazem Darvish Bastami, H. Bagheri, S. Haghparast, F. Soltani, F Hamzehpoor, A., \&Bastami, M.D. . "Geochemical and geo-statistical assessment of selected heavy metals in the surface sediments of the Gorgan 


\begin{tabular}{|l|l|l|l|l|l|l|}
\hline & & & & & & \\
\hline Bangladesh $^{21}$ & & 531 & 105 & 219 & & \\
\hline
\end{tabular}

\section{Table 4. Heavy metal concentrations in different regions of the Indian Ocean}

Issues of contamination of the ocean and the need for its safeguarding were initially envisioned amid the UN gathering on Human Environment in 1972 prompting to the foundation of the United Nations Environment Programmer (UNEP). From that point forward, extensive advance has been laid this bearing coming full circle in the plan and acknowledgment of a few global traditions and conventions with respect to different toxins and their control22.

Limits of EEZ are still not unmistakably differentiated between numerous nations, but rather marine contamination knows no wildernesses. Clashes about the privilege of abuse of assets and obligations of controlling contamination have begun emerging. There are numerous nations which don't have the abilities to overview their EEZ and keep up a reconnaissance. These nations regularly sanction ships from the created nations to carry out the occupation for them. This is positively going to make issues later on.

The world realizes that the main global clash about marine living assets occurred route back in the late sixties between Great Britain and Iceland over angling rights and was known as the 'Cod War'. Who has overlooked the trademark raised by the Icelanders against the British, "God spare the God" Universal projects ought to remember these critical perspectives since it is just such projects which can illuminate such question.

Bay, Iran,” Marine Pollution Bulletin, 64, no.12, (2012), 2877-2884.

21 D Acevedo-Figueroa, B.D Jiménez, and C J Rodriguez-Sierra, "Trace metals in sediments of two estuarine lagoons from Puerto Rico," Environmental Pollution, 141, no.2, ( 2006), 336-342.

22 J.N Holeman, "The sediment yield of major rivers of the world," Water Resources Research, 4, (1986): 787-797. 


\section{Conclusion}

The Countries surrounding Indian Ocean have about $21 \%$ of the world's population. This huge population poses a serious threat to the marine environment. The socio-economic conditions of these developing nations precautionary measures towards minimizing marine pollution is not among the top priorities. People should be made aware of sustainable use of marine resources and least discharge of any kind of waste in the marine water. The ocean current and tidal system of Indian Ocean does not allow free exchange of water with other oceans. The pollutants dumped in this ocean will remain enclosed in the vicinity for longer periods of time, therefore impact of marine pollution in the region will be more immediate, long lasting and highly damaging to the ecosystem.

It has been observed that a number of conventions and treaties have been formed and signed by the countries surrounding the Indian Ocean the chemical analysis of the sea water proves that strict compliance is not taking place. It is strongly recommended that instead of making new protocols for saving the environment, stringent measures should be taken to prevent marine pollution in light of existing regulations.

Whatever are the laws in these countries on marine pollution, strict implementation of these laws is seriously desired to set some example ,so that prospective polluters get a warning to refrain themselves from marine pollution.

Because of some unique tourist attractions, many tourists visit these countries every year and there are many hotels alongside the beaches. The Waste management system is unknown in most of these countries and in the absence of such initiative, most of the waste produced due to domestic or industrial use, the sea is the ultimate destination for waste disposal and thus the issue is turning to be worse day by day.

Realizing the fact that safe, hygienic and sound marine environment will attract more investment in this region in different ways and relying on the age-old adage 'prevention is better than cure', the licensing and monitoring authority should be vigilant too. The after-license monitoring activities should be continuous and rigorous. Such authorities can arrange training programs for the license holders, which will allow them 
to minimize marine pollution. With all such coordinated efforts, this world will be a better place to live in. 